\title{
Simulation of Wheatstone Bridge for Measurement of Resistances
}

\author{
Nigmet KOKLU $^{* 1}$, Dundar YENER ${ }^{2}$, Hamdi Sukur KILIC ${ }^{3}$
}

\begin{abstract}
Accepted $15^{\text {th }}$ August 2014
Abstract: Vast developments in information and technology era necessitate implementation of technology reinforced teaching \& learning. Information and communication technologies remove the negative effects of preparation and understanding problems. Scientist admit that animations and simulations widely contribute education by learning through experience. Abstract courses like physics complicate comprehension of student therefore alternative teaching methods like animation and simulation are used. In this study, we had benefit of animations for achieving better comprehension on teaching "Resistance Measurement with Wheatstone Bridge". Primarily, definitions about the topic are given as animations then, the simulation. Following the directions given to students, calculation of unknown resistance through entering values in simulation with aiming students to understand what Wheatstone bridge is used for. The bridge circuit is built in simulation on computer environment and calculation of the unknown resistance per student is procured by monitoring the change on galvanometer. Besides, derivation of the formulas are showed in animations aiming minimizing misconception about topic and better comprehension.
\end{abstract}

Keywords: Wheatstone Bridge, Animation, Simulation, Physics Education

\section{Introduction}

It is shown that using technologies in education quicken the learning process and increase the performance in several studies. When the similar studies made in the USA are controlled, the performance of the students of technologic application helped classes increase three times in mathematics success and two times in biology success compared to classes using classical teaching techniques [1]. Especially in our country access of the libraries to the modern resources are limited, internet technologies become more important [2].

Simulations are education models which present a real situation, event or process by simplifying it by using computer support. Simulations remove the time, cost and other problems which may arise in real time applications and give students ability to see the situations in almost same as real environment. An educational simulation can be defined as model of an event or activity. Learning process appears during the time when the user gets interactive with the simulation. Because the user can change the experiment parameters and control of the event, animations and videos are out of this definition.

Computer supported education applications help the students to built the concepts which are very hard to grasp and understand easily by using the aid of computer software simulations especially designed for hard to grasp abstract concepts and letting the students interactively participate learning and simulation process. Moreover, it is known that using simulations are more effective then animations because simulations let the users change some parameters and observe the results almost immediately [3]. Consequently, properly designed simulations and simulation based exercises generally allow students show the real reactions to the situations and increase the learning speed [4]. Noted by [5] "Complex information presented to the students are simplified by the using the technology, let the students learn by performing and living the conditions. For example, life

${ }^{1}$ Technical Sciences Vocational High School, Selçuk University, Campus, 42031, Konya/Turkey

* Corresponding Author: Email: nkoklu@selcuk.edu.tr

\# This paper has been presented at the International Conference on

Advanced Technology\&Sciences (ICAT'14) held in Antalya (Turkey), August 12-15, 2014. threatening situation experiments can be prepared in computer environment and simulated to see the experimentation environment, to perform the

experiment and to observe the results to learn by the students" supports the computer aided learning by using simulations. Addition to ability of simulations to let the students perform hard or impossible to realize experiments and active use the set, they are advantageous financially and provide time save, safety and motivation $[6,7]$.

According to results of the research by [8] students have mentioned an expectancy of the necessity of the computer aided education, an increase in the interest to the Physics classes in the schools, and realization of effective learning.

It is observed that the experimental student groups developed more positive approach to science classes which use computer aided learning methods. Simulation is simplification and abstraction of real life situations and applications. The object of many simulations is to narrate the sequential events and knowledge [9].

Some researchers have defended the use of computers to increase the science education quality, thus to make students to gain the skills related to concepts along with the skills of high reasoning. Shayer and Adey are evaluated reasoning and concept related skills through Europe general in science education students in their study. They compared and the applied methods each other in their research results. Results of the research proved that computer aided science education is meaningful in this context but students' skill of reasoning and skills related to the concepts should also be observed and these two approaches should be weaved together [10].

Simulations are more effective and functional than both exercise application software and teaching programs. They can be used in any desired way and in any desired classroom environment, classroom teaching involving the whole students, group studies, small groups or individual student participations to reach the objects. Simulations are preferred over the other teaching software in science education [11,12,13, 14 and 15].

In this study, an animation is used to increase comprehension of the students when the subject of resistance measurement by using Wheatstone bridge is presented. In the study, experiment about Wheatstone bridge for resistance measurement which is performed by the students at laboratory environment is 
transported to virtual environment aiming better learning. First of all, animations of definitions about experiment and the subject are given in computer environment. Later, experiment simulation is formed. It is aimed that students' understanding of how Wheatstone bridge is working and calculation of resistance values by changing the resistance values on the simulation by instructing students properly. Moreover, conducting bridge circuit is simulated to follow the change in galvanometer to measure the unknown resistance value by the students, to show how to derive the equations and to comprehend the concepts of Wheatstone bridge easily. Hence, concept confusions about the subject are aimed to minimize.

\section{The Object And Importance Of The Study}

Physics classes are one of the common classes in many faculties, colleges and junior colleges and universities. Physics classes consist of two parts known as theoretical and practical parts. Theoretical parts generally are realized in classrooms but practical parts are performed in laboratories. Generally, university faculties do not have physics laboratories except Education and Science Faculties. As a result many practical applications and experiments cannot be properly performed. Most of the time classes only consist of theoretical parts. This study is prepared as an animation and simulation class material to support the Physics classes.

It is thought that animation and simulation class material help students to understand the abstract concepts, to learn the practical parts in detail and by simplification about the subject of Wheatstone bridge resistance measurement which may be hard to comprehend in parts by the students. Thus, students may easily comprehend the subject and repeat the experiment as desired as possible. It is also aimed increase in success and motivation, more comprehensive understanding of the concepts by this method.

Our study let the students perform the experiments related to the subject in schools and colleges where there is not enough laboratory environment and experimental materials [16].

\section{Application}

In this study, animations are used to better comprehension of the subject of Wheatstone bridge resistance measurements in the classroom subject presentation. In our study, experiment about Wheatstone bridge for resistance measurement which is performed by the students at laboratory environment is transported to virtual environment aiming better learning. First of all, animations of definitions about experiment and the subject are given in computer environment. Later, experiment simulation is formed. It is aimed that students' understanding of how Wheatstone bridge is working and calculation of resistance values by changing the resistance values on the simulation by instructing students properly. Moreover, conducting bridge circuit is simulated to follow the change in galvanometer to measure the unknown resistance value by the students, to show how to derive the equations and to comprehend the concepts of Wheatstone bridge easily. Hence, concept confusions about the subject are aimed to minimize.

In this study, when the animations and simulations are prepared, relation of the animations and simulations to the subject, attraction of attention about subject and visuals are considered in priority. Attractiveness of the animations and simulations make students enjoy the application. While the simulations and animations are presented, the verbal knowledge which is given to the students and animations and simulations, are planned to be coherent each other. The knowledge to be gained by the students is also carefully planned to be in the class study for effectiveness of the animation and simulation. Thus, the mind of the student is not filled up by the unrelated garbage but students are planned to make connection between the previous class subjects. Comprehensibility of the figures and textures, consistency of used colours created movements in the computer are also given careful attention. The other factors like used colours not to be eye straining and clearness of the pictures are also carefully considered. Sound are also carefully added to the animations thus giving the vividness to the leaning process while presenting the educational elements and helping the students get the necessary clues about the subjects. Unexaggerated and natural sounds are preferred. Figures are chosen according to the ages of the students. Font style, type, colour and points are chosen according to their readability and animation movement perception compatibility. Every animation and simulation has forward and backward buttons to pass the desired part and calculate button is used to calculate numerical results. Long texts are avoided, thus presented knowledge to be more attractive and readable [16].

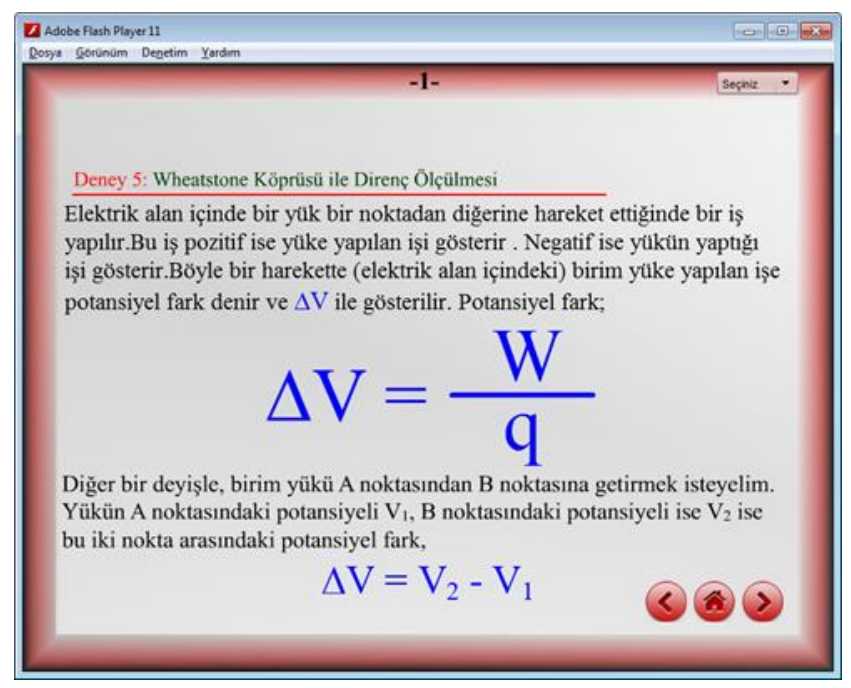

Figure 1. Resistance measurement by wheatstone bridge

In Figure 1, the definition of the potential difference is given for better understanding of subject and it goes over the basic knowledge. Thus students make connection between the previous class subjects. Previous memories are stimulated easier comprehension of the subject is planned.

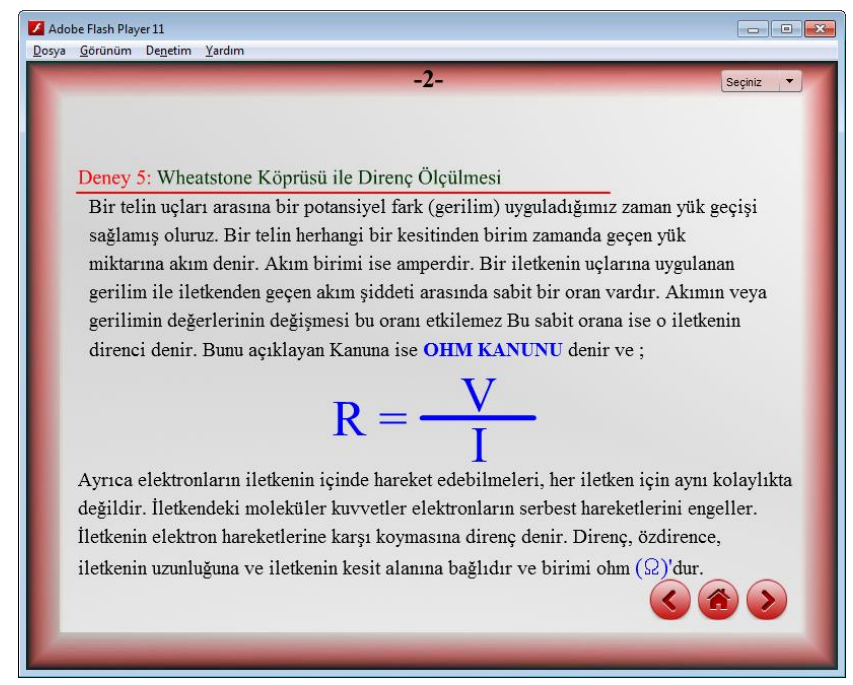

Figure 2. Presentation of Ohm's Law as a formula 
In Figure 2 definition of the current, Ohm's law and formula, definition of resistance and unit are given. So, students make connection between the previous class subjects and overcome any shortcomings if there is a hole in background knowledge or concept mistakes.

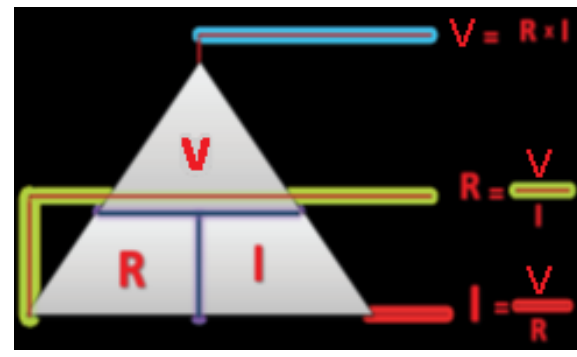

Figure 3. Animation presentation of Ohm's Law

Animation of the Figure 3 visualizes the Ohm's Law formula and the objectives of the animation are to help to ease the learning of the formula by the students and to keep the formula longer in their memory.

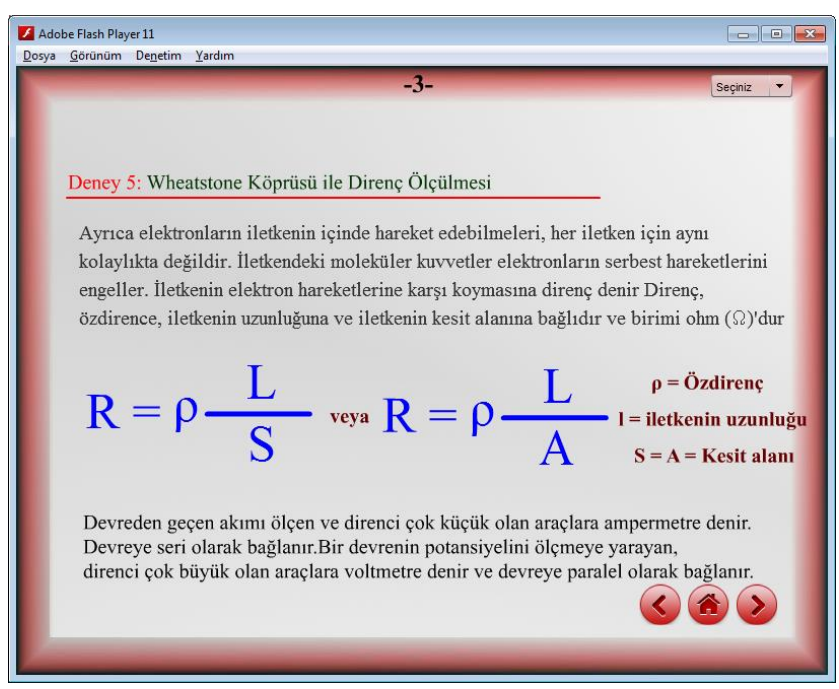

Figure 4. Resistance effecting factors

In the animation of Figure 4, definition of resistance, factors effecting resistance, the unit of resistance, definition of Ammeter and Voltmeter. Moreover, symbol terms like resistivity, length of the conductor, cross section area are explained thoroughly.

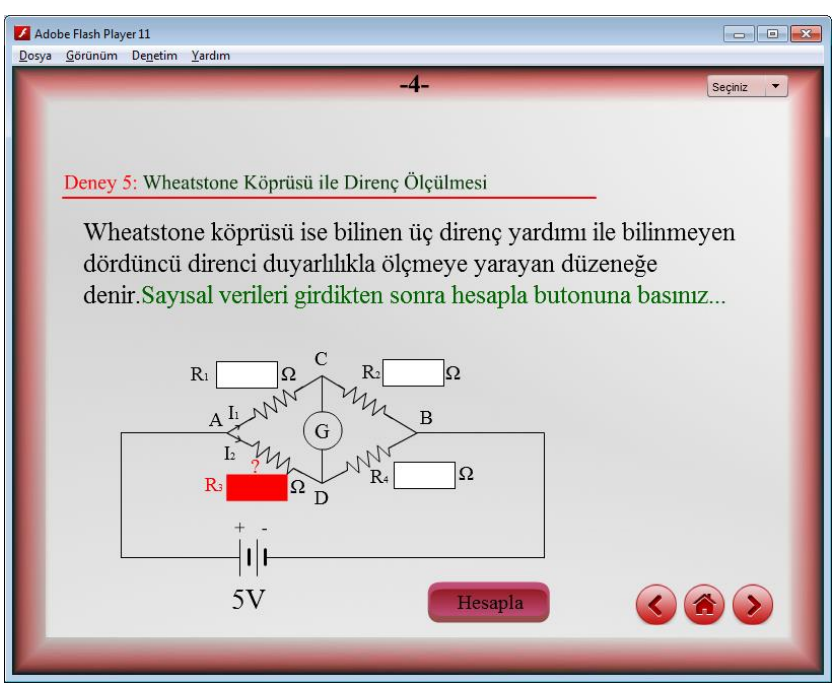

Figure 5. Wheatstone bridge definition and its circuit.
In Figure 5 necessary descriptions related to the subject are given and required formulas are given. The empty spaces in the simulation here are aimed for students to fill and calculate the results so they get better understanding of the subject.

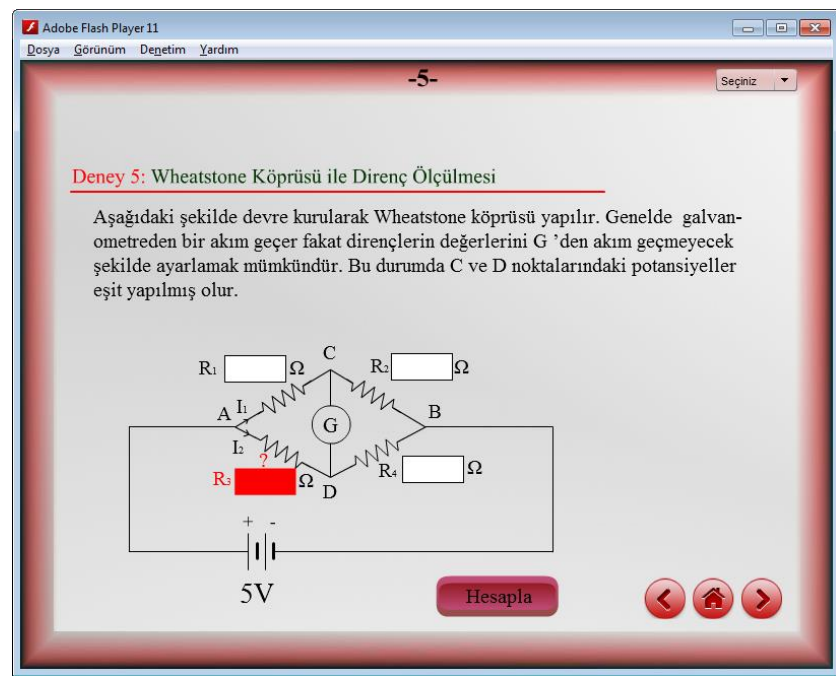

Figure 6. An example of Wheatstone bridge for resistance measurement.

In Figure 6, the students are asked to calculate resistor R3 by entering numerical values to the empty spaces in the simulation. So, enjoyable learning process of the subject and keeping high concentration throughout class duration are aimed.

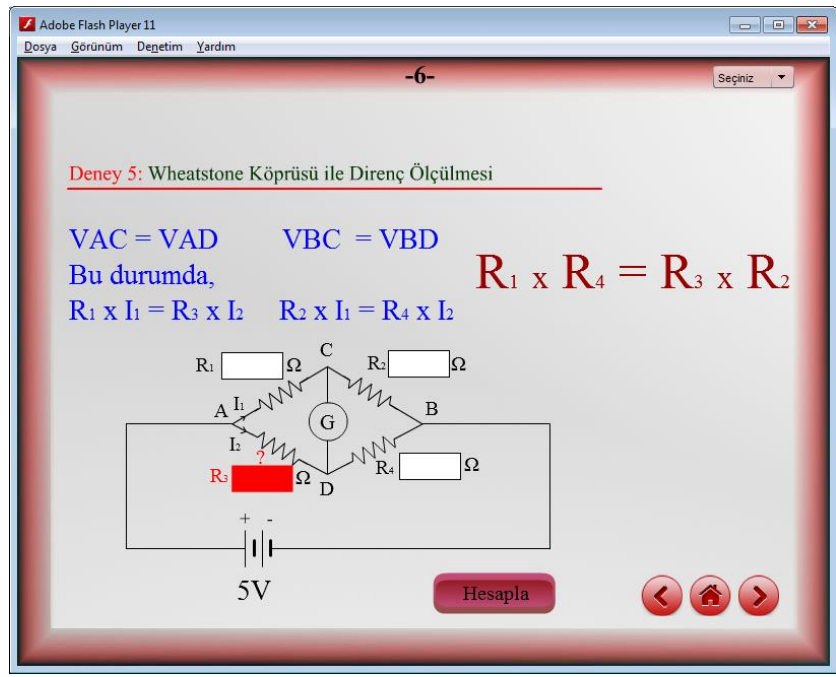

Figure 7. Formulization of Wheatstone bridge

In Figure 7, Wheatstone bridge related formulas are shown as simulation. As can be seen in the Figure 7, the animations differ from the simulations because it is possible to interfere in the simulation from outside. Simulation is not just the presentation of the experiment; it is also the realization of the experiment in computer environment by the individual. Nonetheless, guidance is also present. As can be seen in the Figure 7, students can change numerical values; they may increase or decrease the values. They may observe different results and reach conclusions according to changes made in resistance values. 


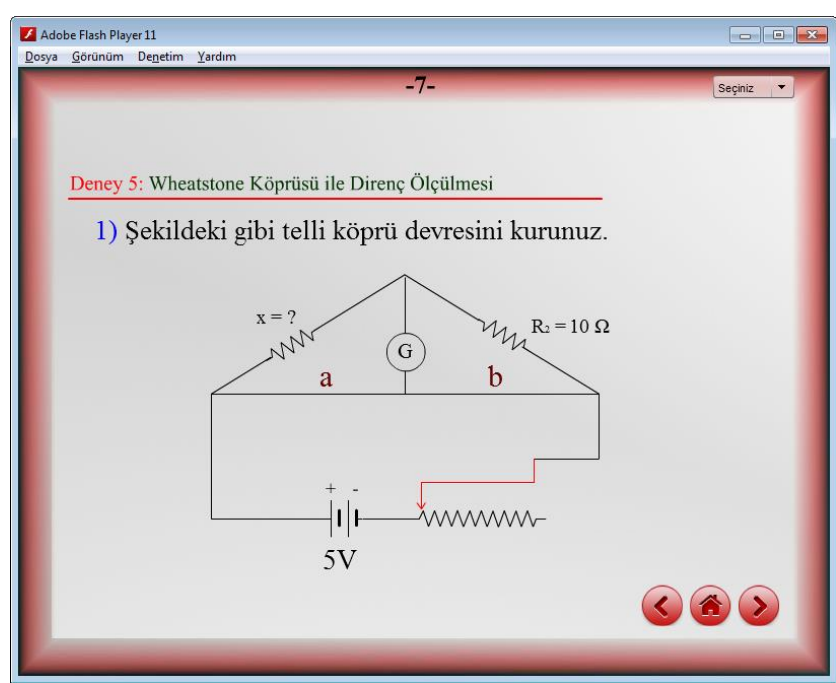

Figure 8. Setting up the circuit

In the Figure 8, a conductor bridge is set up as an example of Wheatstone bridge. Simulation in the Figure 8 gives some insight to the students how an experiment of Wheatstone bridge resistance measurement experiment can be simulated in the virtual laboratory.

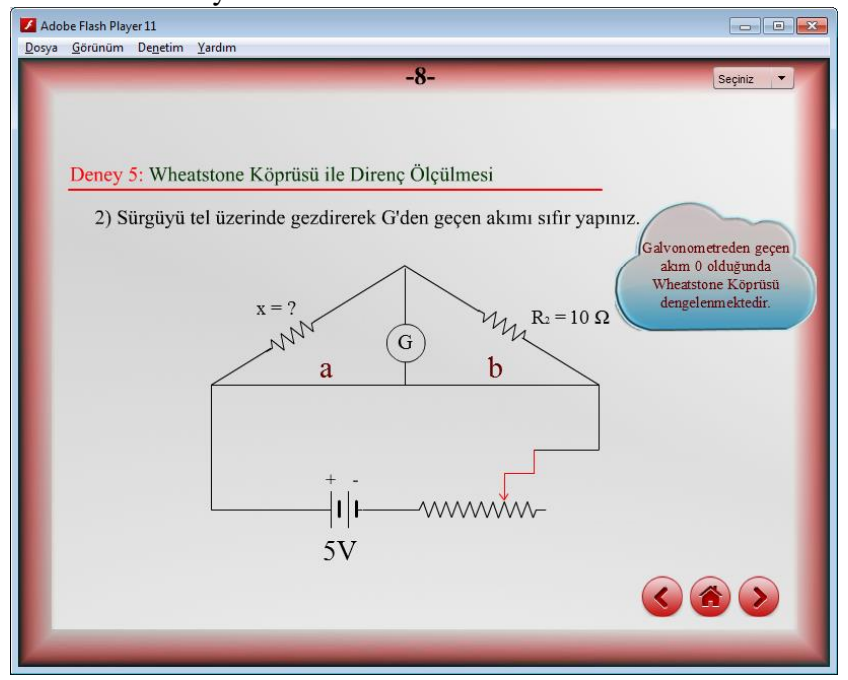

Figure 9. Example of Wheatstone bridge for resistance measurement

In the simulation of Figure 9, students can move the slide over the conductor and zero the current passing through the galvanometer and as a result balance the bridge.

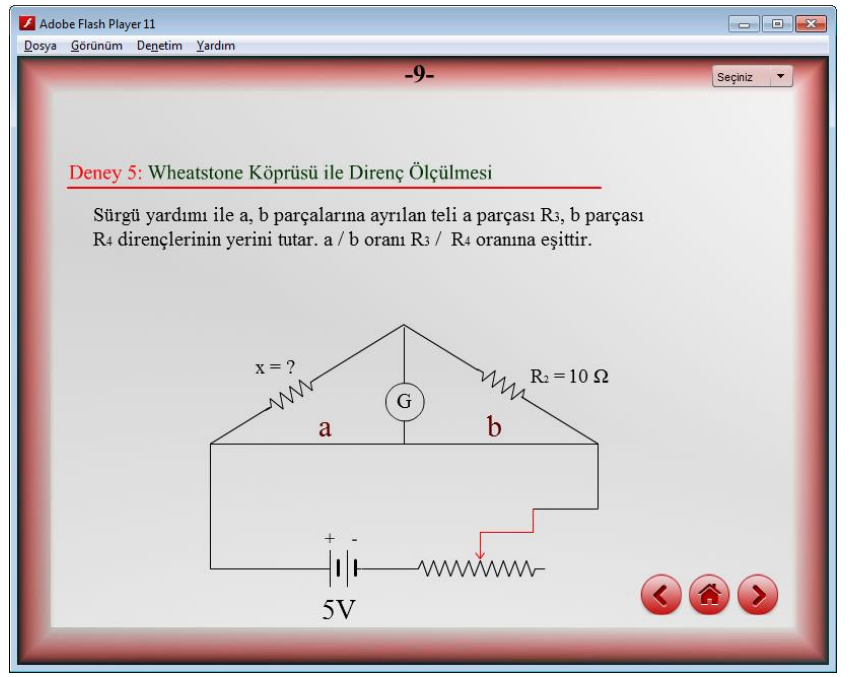

Figure 10. Deriving the formulas according to experimental results
In Figure 10 to calculate unknown resistance $\mathrm{x}$ a formula derivation must be made. To do this, necessary information is given in the animation. When the forward button in the animation is clicked derivation of the formula step by step explained.

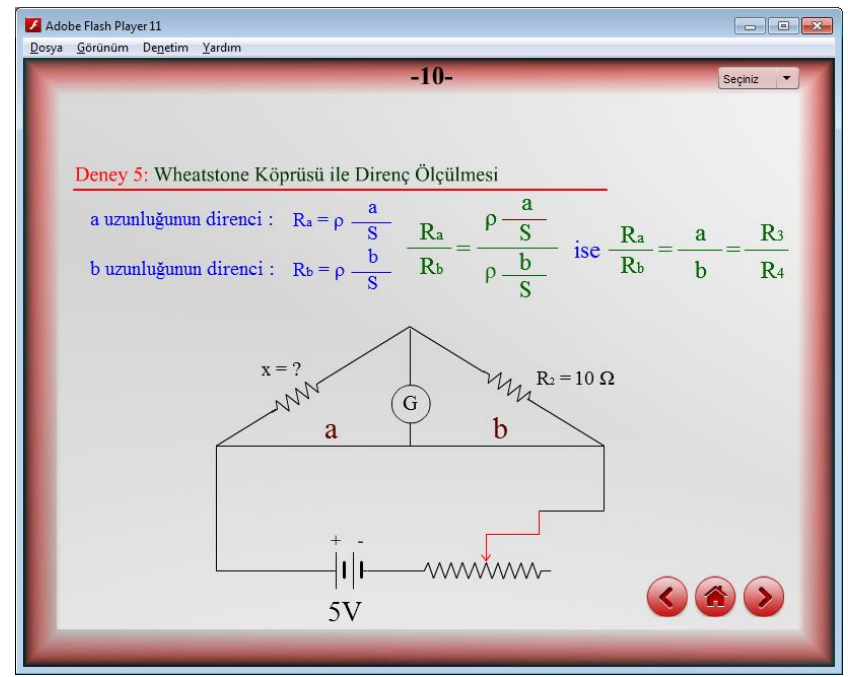

Figure 11. Derivation of formulas in the experiment of Wheatstone bridge for resistance measurement.

In Figure 11 formulas for calculation of unknown resistance $\mathrm{x}$ by using cross section area, and length are given.

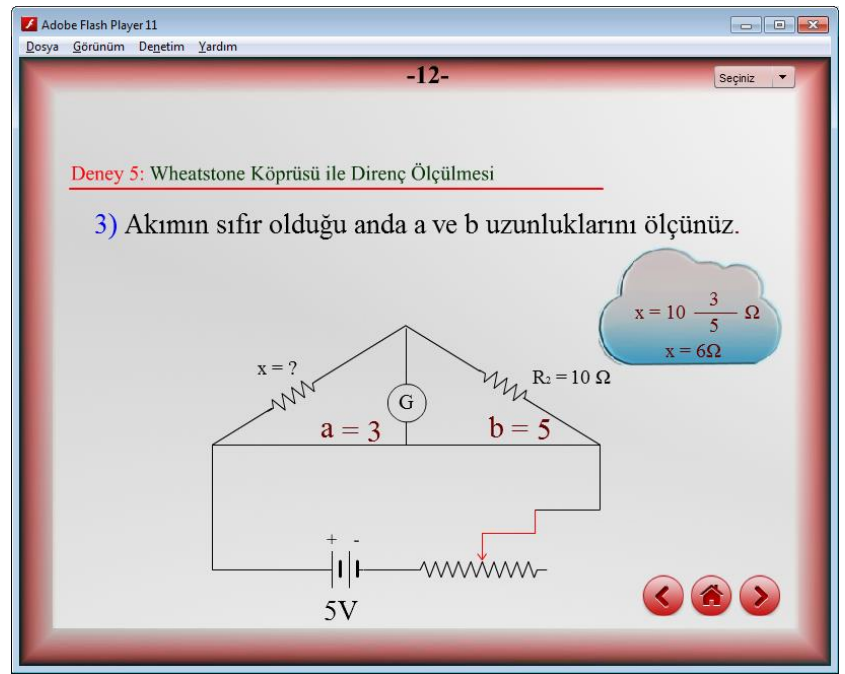

Figure 12. Example of Wheatstone bridge for resistance measurement

In Figure 12, unknown resistance value is calculated by using the formula given in the previously animation. When the forward button is clicked, calculation of resistance $\mathrm{x}$ is explained step by step [16].

\section{Conclusion}

Experiments are presented and performed comfortably and become enjoyable by using animations and simulations with the help of computer software. All facilities of Web based educational technologies are used for better learning of Physics laboratory and not to make any mistakes in laboratory studies. The greatest hardness encountered when designing application pages are appeared in the process of animation and simulation design.

Some of the students participate to the experimental work report that changing and reentering the values as desired ease the understanding of the subject. Students also report that small 
changes which may not be observable in real life can easily be observed in computer screen. Step by step following of a lengthy experimental process as desired from start to stop is reported to be helpful to understand and comprehend the subject. Many of the students are reported that many subjects of the Physics classes are boring and uninteresting, but they reported that they have not bored during the simulation; on the contrary they have liked the simulation process.

Some of the students participated to the study have wanted to prepare similar class materials themselves.

The effect of the animation and simulation course material on the success, motivation, concept learning and mistakes of the students can be studied in the future.

Simulations can be used in Physics classes because they materialize the abstract concepts and also they let performing of hard to realize and dangerous experiments.

Teacher and teacher candidates can be trained to prepare presentations of subjects by using animation and simulation and to design animations and simulations.

\section{References}

[1] Şen, A,I .(2001), "Fizik Öğretiminde Bilgisayar Destekli Yeni Yaklaşımlar", Gazi Üniversitesi Gazi Eğitim Fakültesi Dergisi, Cilt 21, Sayı:3, 61-71.

[2] Çakmak, O. Fen Eğitiminin Yeni Boyutu: BilgisayarMultimedya-İnternet Destekli Eğitim, Buca Eğitim Fakültesi Dergisi, Özel Sayı:11, , Dokuz Eylül Üniversitesi, İzmir, 1999, pp.116-125.

[3] Demirci N, Bilgisayarla Etkili Öğretme Stratejileri ve Fizik Öğretimi, Nobel Yayınları, Ankara, 2003.

[4] URL-1., http://www.enocta.com/tr/kaynaklar_makale_detay.asp?url $=100$, Access Date: 17.10.2008.

[5] İșman, A., Sakarya İli Öğretmenlerinin Eğitim Teknolojileri Yönündeki Yeterlilikleri, The Turkish Online Journal Of Educational Technology, Vol. 1, No 1, 2002.

[6] Rodriguez, R. N., Recent Developments in Process
Capability Analysis, Journal of Quality Technology, Vol:24, No:4, 1992

[7] Tekdal, M., Etkileşimli Fizik Simülasyonlarının Geliştirilmesi ve Etkin Kullanılması, V. Ulusal Fen bilimleri ve Matematik Eğitimi Kongresi, Ankara, 2002.

[8] Yiğit,N. ve Akdeniz,A.,R., Fizik Öğretiminde Bilgisayar Destekli Etkinliklerin Öğrenci Kazanımları Üzerine Etkisi: Elektrik Devreleri Örneği, Gazi Üniversitesi Gazi Eğitim Fakültesi Dergisi, Cilt 23, Sayı 3, 2003, pp.99-113.

[9] Şengel,E. , Özden ,M., Y. ve Geben, Ö., Bilgisayar Simülasyonlu Deneylerin Lise Öğrencilerinin Yer Değiştirme ve Hız Kavramlarını Anlamadaki Etkisi", http://www.tmyo.edu.tr (23.03.2008)

[10] Shayer, M. ve Adey, P. S., Towards a Science of Science Teaching, Heinemann, London, 1981.

[11] Andaloro, G., Modeling in physics teaching: The role of computer simulation. International Journal of Science Education, 13 (3), 1991, pp.243-254.

[12] Mintz, R., Computerized Simulation As An Inquiry Tool, School Science and Mathematics, 93(2), 1993, pp.76-80.

[13] Richards, J., Computer simulations in the science classroom, Journal of Science Education and Technology, 1(1), 1992, pp.67-80.

[14] Ronen, M., Integrating computer simulations into high school physics teaching, Journal of Computers in Mathematics and Science Teaching, 11(3- 4), 1992, pp.319329.

[15] Simmons,P.E.;Lunetta, V.N., Problem-solving behaviors during a genetics computer simulation: beyond the expert/novice dichotomy. Jaurnal of Research in Science Teaching,30, 1993, pp.153-173.

[16] Köklü, N., Genel Fizik Laboratuvarında Başarı ve Akılda Kalıcılık Etkilerinin Artırılmasına Yönelik Animasyon, Simülasyon ve Analojik Modellerin Geliștirilmesi, Doktora Tezi, Selçuk Üniversitesi Fen Bilimleri Enstitüsü, Konya, 2015. 